\title{
Bangladesh Withdraws from Customary International Law: The Practical Implications of Trifling with Custom
}

\author{
Ehsan A. Siddiq ${ }^{1}$ \\ ${ }^{1}$ A defence counsel at the International Crimes Tribunal of Bangladesh, Dhaka, Bangladesh \\ Correspondence: Ehsan A. Siddiq, The Law Counsel, City Heart (14 ${ }^{\text {th }}$ Floor), 67 Naya Paltan, Dhaka-1000, \\ Bangladesh. E-mail: ehsan.siddiq@hotmail.com
}

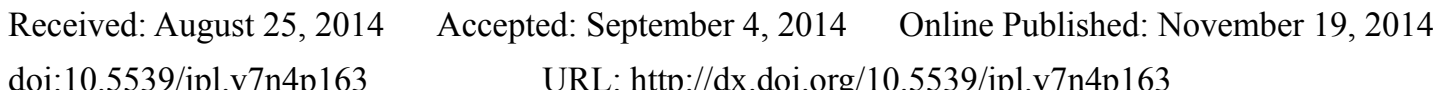

doi:10.5539/jpl.v7n4p163 URL: http://dx.doi.org/10.5539/jpl.v7n4p163

\begin{abstract}
This Article examines how the Supreme Court of Bangladesh relied on a theoretical model of Customary International Law (CIL) advanced by Professors Curtis A. Bradley and Mitu Gulati to withdraw from the rules of CIL. It explores how the Supreme Court applied the same reasons and relied on the same authorities as did the proponents of this model to effect a withdrawal. Although Bradley and Gulati advanced their model as an academic experiment, this did not deter the Supreme Court from applying the model to withdraw from the rules of CIL which define the jus cogens offence of crimes against humanity and to eventually sentence to death an opposition political leader on the basis of such withdrawal. Bradley and Gulati's model of CIL has been subject to a lot of scholarly criticism and the Bangladesh experience has to some extent justified these criticisms. This Article shows how countries which are prevented from achieving certain outcomes or realizing certain goals because of CIL may simply adopt Bradley and Gulati's model to withdraw from its rules.
\end{abstract}

Keywords: Bangladesh, customary international law, crimes against humanity

\section{Introduction}

On September 17, 2013, Bangladesh asserted its right to withdraw unilaterally from customary international law (CIL). In the landmark case of the Government of Bangladesh v. Abdul Quader Molla, ${ }^{1}$ the Supreme Court of Bangladesh held that the rules of CIL would not apply to the determination of the elements of crimes against humanity $^{2}$. In doing so, the Supreme Court relied on a theoretical model of CIL advanced by Professors Curtis A. Bradley and Mitu Gulati ${ }^{3}$ in an article published in The Yale Law Journal in 2010. This model, which was introduced to generate academic debate to "better understand" 4 international law, challenged the current conception of CIL by allowing nations to unilaterally withdraw from it.

Although the Supreme Court in its decision made only one fleeting reference to Bradley and Gulati ${ }^{5}$, and none at all to their article, it is clear that the rejection of CIL was based on their proposed model. There is a similar reliance on the $18^{\text {th }}$ century treatise of Emmerich de Vattel ${ }^{6}$ and the decision even cites the same passage of the same U.S. Supreme Court judgment relied upon by them. ${ }^{7}$ Moreover, the criticisms that have been made of Bradley and Gulati's model may also be validly made of the reasonings of the Supreme Court. Further, the

\footnotetext{
${ }^{1}$ Criminal Appeal Nos. 24-25 of 2013 (Bangl. Sup. Ct., App. Div.), September 17, 2013) (Molla Appeal Judgment). This is the judgment of the Appellate Division of the Supreme Court of Bangladesh, which serves as the appeals chamber of the International Crimes Tribunals of Bangladesh. By its judgment, the Supreme Court sentenced Mr. Abdul Quader Molla to death for committing crimes against humanity. Mr. Molla was hanged on December 12, 2013, 7 days after the text of the judgment was made public. Retrieved from http://www.supremecourt.gov.bd/scweb/documents/601845_CrlA_24_25_2013.pdf

2 See infra section 3.1 .

${ }_{3}^{3}$ Bradley, C. A. \& Gulati M. (2010). Withdrawing from international custom. Yale Law Journal, 120, 202-275.

${ }^{4}$ Ibid., p. 275.

5 Molla Appeal Judgment, p. 109.

${ }^{6}$ De Vattel, E. (1758/1916). The law of nations or the principles of natural law applied to the conduct and to the affairs of nations and of sovereigns. (James Brown Scott ed., Charles G. Fenwick Trans.). Washington, DC: Carnegie Institution of Washington.

${ }^{7}$ See Bradley \& Gulati (2010), p. 220 where Bradley and Gulati rely on the opinion of Justice Chase in Ware v. Hylton 3 U.S. (3 Dall.) 199 (1796) and quote him as holding that CIL "is founded on tacit consent; and is only obligatory on those nations, who have adopted it." The same phrase is relied on by the Supreme Court in the Molla Appeal Judgment, p. 110.
} 
Supreme Court was clearly influenced by Bradley and Gulati's argument that the prevailing view of CIL was imposed on less civilised states by western powers. ${ }^{8}$ Finally, the decision reveals that the Supreme Court, at least on one occasion quoted directly from their article, ${ }^{9}$ although it failed to attribute the quote to its authors. In fact, despite the attempts to conceal the influence of Bradley and Gulati, evidence of the Supreme Court's reliance on their model of CIL is overwhelming. ${ }^{10}$

By virtue of this decision, Bangladesh has probably become the first nation in modern times to exercise a right of unilateral withdrawal from CIL. Bradley and Gulati would no doubt be pleased that Anthea Roberts's criticism that they "can cite to no examples of states arguing for a right of withdrawal" 11 can now be rectified. Their model of CIL has been adopted by Bangladesh and it is no longer only confined to the academic laboratory. ${ }^{12}$ Bangladesh's position on international law can now form the basis of a case study for Bradley and Gulati's proposed model of CIL.

Although it is not the purpose of this Article to critique Bradley and Gulati's proposed model, it can safely be said that their model has undermined CIL. Bradley and Gulati have trifled with custom, the consequences of which were felt in Bangladesh. In Bangladesh, the definition of crimes against humanity no longer conforms with the definition prevailing in the rest of the world. The decision of the Supreme Court has highlighted the consequences of adopting Bradley and Gulati's model of CIL. It has shown how states prevented by the rules of CIL from achieving certain outcomes, may simply adopt Bradley and Gulati's model to withdraw from them. ${ }^{13}$ Section 2 of this Article examines how the Supreme Court relied on Bradley and Gulati's article in The Yale Law Journal to adopt their model of CIL and Section 3 discusses the implications of the adoption of this model.

\section{The Supreme Court of Bangladesh's Adoption of the Default View}

\subsection{The Mandatory and Default Views of CIL}

The prevailing view of CIL is that its rules are not subject to any right of unilateral exclusion but binds all states "irrespective of their individual wills." still form part of international law. ${ }^{15}$ No state can withdraw from the rules of CIL unless it has persistently objected to it at the time of its emergence as a rule. Bradley and Gulati term this as the Mandatory View of CIL ${ }^{16}$ and admit that this view is "canonical"17 and reflects the "conventional wisdom."18 This they contrast with what they call the Default View, according to which nations may unilaterally withdraw from the rules of CIL, subject to certain restrictions. ${ }^{19}$ Under this model, CIL is viewed as "binding only until such time as a nation adequately announced that it no longer intended to continue adhering to the rule. ${ }^{.20}$ In their works, Bradley and Gulati describe the Default View as challenging conventional wisdom ${ }^{21}$ and endeavour to advance this view to "improve this body of international law"22 by "thinking creatively." ${ }^{23}$ It is relying on this creative formulation of CIL that the Supreme Court of Bangladesh withdrew from its rules.

\footnotetext{
${ }^{8}$ See infra section 2.2.3.

9 See Bradley \& Gulati (2010), p. 219. Bradley and Gulati state that CIL "rules were binding only on nations that continued to accept them". This is quoted by the Supreme Court in the Molla Appeal Judgment, p. 109.

${ }^{10}$ The Supreme Court's apparent reluctance to acknowledge its reliance on Bradley and Gulati is conceivably due not only to the theoretical nature of their model of CIL but also because their model has been subject to severe criticism and is without any precedence of application by any state. The Supreme Court of Bangladesh no doubt had in mind that its predecessor, the Supreme Court of Pakistan had been subject to criticism when it too relied on a theoretical model. See text accompanying infra notes 73-78.

${ }^{11}$ Roberts, A. (2010). Who killed article 38(1)(B)? A reply to Bradley and Gulati. Duke Journal of Comparative and International Law, 21, 173-190 at p. 174.

12 Ibid.

${ }^{13}$ See infra section 3.3 .

${ }^{14}$ Fitzmaurice, G.G. (1956). The foundations of the authority of international law and the problem of enforcement. Modern Law Review, 19, $1-13$.

${ }^{15}$ See Crawford, J. (2012). Brownlie's Principles of Public International Law. Oxford, England: Oxford University Press, p. 28.

${ }^{16}$ Bradley \& Gulati (2010), p. 205.

${ }^{17}$ Ibid., p. 205.

${ }^{18}$ Ibid., p. 226.

${ }^{19}$ See ibid., p. 213, pp. 215-18.

${ }^{20}$ Ibid., pp. 215-16.

${ }^{21}$ See Bradley, C. A \& Gulati, M. (2011). Mandatory versus default rules: How can customary international law be improved? Yale Law Journal Online, 120, 421-454 at p. 423. Retrieved from http://yalelawjournal.org/2011/4/12/bradley-gulati.html

${ }^{22}$ Ibid, p. 421.

${ }^{23}$ Ibid.
} 


\subsection{The Supreme Court's Reasons for Adopting the Default View}

Although Bradley and Gulati admit in their works that the Mandatory View is the preeminent understanding of CIL, the Supreme Court of Bangladesh has completely ignored its existence. For it, there is only one view of CIL- the Default View. The Supreme Court proceeded with its judgment in Molla as if the Default View is the prevalent view and supported it with the arguments advanced by Bradley and Gulati in their article. ${ }^{24}$

\subsubsection{Comparison with Treaties}

Just as Bradley and Gulati advanced their case for the Default View by proposing that treaties and CIL be treated alike, so too did the Supreme Court. For Bradley and Gulati, both the similarities and the differences between treaties and CIL suggest that there ought to be a right of withdrawal from CIL. To them it is not obvious "why it should be easier to exit from treaties than from CIL, especially given the significant regulatory overlap that exists today between treaties and CIL." ${ }^{25}$ They also suggested that since CIL does not arise from express negotiation and does not require any domestic act of ratification to become binding, nations should have greater flexibility to withdraw from the rules of CIL than from treaties. ${ }^{26}$ This analogy between treaties and CIL is not without criticism. ${ }^{27}$ It has been described by critics of Bradley and Gulati as false in that it confuses their respective functions by failing to perceive that a treaty is an "optional commitment" 28 while CIL "sets the ground rules for the international system by imposing a minimum core of binding obligations." 29 However, the Supreme Court unconcerned with the criticisms, took the confusion a step further. As with treaties, the Supreme Court subjected CIL to an incorporation requirement before it could be considered binding under domestic law.

The issue before the Supreme Court in the case of Molla was whether the elements of crimes against humanity under CIL would be directly applicable to the trials in Bangladesh. There was no dispute as to whether crimes against humanity could be tried by domestic courts as they had already been criminalized in Bangladesh by domestic legislation. ${ }^{30}$ However, these crimes were neither defined nor were the elements of the crimes specified under Bangladesh law. ${ }^{31}$ As such, the Supreme Court had to decide whether in the absence of any domestic definition of crimes against humanity, the elements that constitute these crimes under CIL would apply. In this regard, the leading judgment ${ }^{32}$ of the Supreme Court held that "CIL [in] developing international crimes does not impose penal sanctions upon an individual unless the domestic law assimilates the said concepts of international crimes into the body of domestic law. ${ }^{" 33}$ By the term concepts of international crimes the Supreme Court was referring to elements of international crimes. It was not disputed that international crimes such as crimes against humanity themselves were recognised in Bangladesh and could be tried by the domestic courts. What was in dispute was whether the elements (or in the word of the Supreme Court - concepts) of crimes against humanity under CIL would be directly applicable in Bangladesh. Thus, the Supreme Court required an act of assimilation of the elements of crimes against humanity in CIL into domestic law before they could be taken into consideration. This subjection of CIL by the Supreme Court to the same incorporation requirement as treaties manifests a similar (although perhaps more acute) confusion displayed by Bradley and Gulati with

\footnotetext{
${ }^{24}$ Bradley \& Gulati (2010).

25 Ibid., p. 205.

${ }^{26}$ See ibid., p. 204.

${ }^{27}$ See Brilmayer, L. \& Tesfalidet, I. Y. (2011). Treaty denunciation and "withdrawal" from customary international law: An erroneous analogy with dangerous consequences. Yale Law Journal Online, 120, 217-231. Retrieved from http://yalelawjournal.org/2011/1/5/brilmayer-tesfalidet.html

${ }^{28}$ See Roberts (2010), p. 173.

29 Ibid.

${ }^{30}$ International crimes such as genocide and crimes against humanity have been criminalised in Bangladesh under the International Crimes (Tribunals) Act of 1973. The preamble to this Act states that it has been enacted "to provide for the detention, prosecution and punishment of persons for genocide, crimes against humanity, war crimes and other crimes under international law."

${ }^{31}$ Section 3(2)(a) of the International Crimes (Tribunals) Act of 1973 only lists the various crimes against humanity, without defining them or describing their elements. Section 3(2)(a) states:

The following acts or any of them are crimes within the jurisdiction of a Tribunal for which there shall be individual responsibility, namely:-

(a) Crimes against Humanity: namely, murder, extermination, enslavement, deportation, imprisonment, abduction, confinement, torture, rape or other inhumane acts committed against any civilian population or persecutions on political, racial, ethnic or religious grounds, whether or not in violation of the domestic law of the country where perpetrated.

${ }^{32}$ The leading judgment was delivered by Mr. Justice Surendra Kumar Sinha with whom the Chief Justice and two other judges of the Supreme Court concurred.

${ }^{33}$ Molla Appeal Judgment, p. 116 (emphasis added).
} 
respect to the nature and purpose of treaties and CIL.

The Supreme Court's inclusion of an incorporation requirement for CIL was not only unnecessary but also a departure from the position under Bangladesh law and other common law jurisdictions. In Bangladesh, the definition of law $^{34}$ includes CIL. It is also the settled position in the United States that CIL has the status of federal common law. ${ }^{35}$ There was therefore, no further requirement to incorporate CIL into domestic law. Not even the authors of the Default View suggest subjecting CIL to a domestic incorporation requirement. In fact, if the application of CIL had been subject to an incorporation requirement, then the Default View, which advocates a right of withdrawal from CIL becomes redundant. The only explanation for this unnecessary departure is that the Supreme Court had probably felt that by extending the treaty-CIL analogy of Bradley and Gulati further, it could bar CIL at the threshold and undermine it so much so that a withdrawal from its rules would not seem far-reaching.

\subsubsection{Reliance on the Treatise of Emmerich de Vattel}

Like Bradley and Gulati, the Supreme Court of Bangladesh also provided historical support for the Default View in the form of the $18^{\text {th }}$ century treatise of the Swiss commentator, Emmerich de Vattel. Relying on various extracts of Vattel's treatise, Bradley and Gulati argued that the Mandatory View was not always the dominant understanding of CIL but it was thought that its rules "were at least sometimes subject to unilateral withdrawal. ${ }^{36}$ This interpretation of Vattel however, has been described as misleading. Critics of Bradley and Gulati have argued that Vattel never intended the Default View to apply to the rules of natural law, which today form a major component of $\mathrm{CIL}^{37}$ and that according to Vattel " $[\mathrm{t}]$ he Default View was limited to less important questions, on which natural law was indifferent." 38 The Supreme Court of Bangladesh was once again unaffected by the criticism of Bradley and Gulati and in fact disregarded it. Unperturbed, the leading judgment of the Supreme Court relying on Vattel observed that CIL "was based on tacit consent; and bound only those Nations which have adopted it." 39 The leading judgment also observed that "Vattel, Professors Bradley and Gulati, the [e]ighteenth [c]entury writers, draw upon three early [U.S.] Supreme Court cases to show that customary international law rules were binding only on nations that continued to accept them." ${ }^{40}$ The judgment thus concluded that "[i]t is [a] generally accept[ed] principle that international law cannot bind states without their consent" obligation." 42

\subsubsection{Imposition of the Mandatory View on Weaker States}

According to Bradley and Gulati, the Mandatory View of CIL "was used by Western powers to impose their standards on weaker, 'uncivilized' countries." 43 This view was described as "an effort to bind new nations and former colonies to international law rules that had already been worked out by a handful of powerful states." 44 However, in a subsequent article dealing with the criticisms of this characterization of the Mandatory View, Bradley and Gulati admit that their historical analysis was based on a "small portion of the secondary literature" 45 and hence "tentative in nature." tentative analysis of the Mandatory View and took it a step further.

\footnotetext{
${ }^{34}$ Law is defined in Article 152 of the Bangladesh Constitution as "any Act, Ordinance, order, rule, regulation, bye-law, notification or other legal instrument, and any custom or usage having the force of law in Bangladesh" (emphasis added).

${ }^{35}$ See, e.g., Bradley, C. A. \& Goldsmith, J. L. (1997). Customary international law as federal common law: A critique of the modern position. Harvard Law Review, 110, 815-876, where the authors while critiquing this settled position of law, admit that it has "overwhelming approval".

${ }^{36}$ Bradley \& Gulati (2010), p. 215.

${ }^{37}$ See Luban, D. (2010). Opting out of the law of war: Comments on withdrawing from international custom. Yale Law Journal Online, 120 , 151-167 at p. 158. Retrieved from http://yalelawjournal.org/2010/12/8/luban.html; Dodge, W.S. (2010). Withdrawing from customary international law: Some lessons from history. Yale Law Journal Online, 120, 169-192 at pp. 171-75. Retrieved from http://yalelawjournal.org/2010/12/17/dodge.html

${ }^{38}$ Dodge (2010), p. 175.

${ }^{39}$ Molla Appeal Judgment, p. 109 (footnotes omitted).

${ }^{40}$ Ibid., p. 109 (emphasis added).

${ }^{41}$ Ibid., p. 111.

${ }^{42}$ Ibid. (emphasis added).

${ }^{43}$ Bradley \& Gulati (2010), p. 230.

${ }^{44}$ Ibid., p. 206.

${ }^{45}$ Bradley \& Gulati (2011), p. 438.

${ }^{46}$ Ibid.
} 
Relying on the historical analysis of Bradley and Gulati, the Supreme Court rejected the argument that the rules of CIL which had crystallized in the decisions of the various ad hoc international tribunals were applicable in Bangladesh. According to it, those international tribunals were designed for countries without developed judicial systems. ${ }^{47}$ After describing the judicial history of Bangladesh from 1612, the Supreme Court dismissed the need to look into the rules of CIL identified by the international tribunals, holding that "the legal system of Bangladesh is strong enough to hold trial of the perpetrators of [c]rimes against [h] umanity." ${ }^{48}$ Although it dismissed the need to apply CIL in Bangladesh, it however justified the application of CIL to countries where events had led to the setting up of international tribunals by holding that "[t]he administration of justice in those countries is very poor." $" 49$

While Bradley and Gulati suggest that the Mandatory View was imposed on weaker states by powerful states, they do not claim that such powerful states themselves applied the Default View. The Supreme Court however expanded on Bradley and Gulati's historical analysis and seems to suggest that although the Mandatory View can be imposed on countries with weak legal systems, but for countries with established legal systems the Default View applies. As such, according to the Supreme Court, since the Bangladesh legal system is "strong enough," 50 it need not be bound by the rules of CIL which are only meant to be imposed on weaker countries.

Thus, the Supreme Court relying on the works of Bradley and Gulati undermined the universal application of CIL and thereby laid the grounds for the adoption of the Default View.

\section{Implications of Adopting the Default View}

\subsection{A Withdrawal in Disguise}

Having established its case for the Default View, the Supreme Court of Bangladesh proceeded to withdraw from the rules of CIL insofar as they determine the elements of crimes against humanity. The Supreme Court however stopped short of using the term "withdraw" to describe its position on CIL. Yet it is clear that it had exited from some of its rules. This exit was accomplished in a circuitous and often confusing manner. Although the leading judgment held that "there is nothing repugnant to CIL in the [Bangladesh legislation], which is consonant with the provisions of CIL," ${ }^{51}$ it still refused to recognise the elements of crimes against humanity under CIL. The inevitable conclusion therefore is that since the Supreme Court had refused to apply CIL despite having admitted that there was no inconsistency with domestic legislation, it had by judicial pronouncement withdrawn from its rules. The Supreme Court held that the submissions of the defence that:

$[\mathrm{T}] \mathrm{o}$ constitute the [c]rime[s] against [h] umanity, the elements that there must be an attack; that the accused must have nexus with the attack; that the attack must be against [a] civilian population; that the attack needs to be widespread and systematic; that there must be existence of prior plan or policy and that there must be an attack on political, racial, ethnic or religious grounds are not only misleading but also foreign to the [Bangladesh legislation]. ${ }^{52}$

The Supreme Court did not clarify why it considered the defence submissions on the applicability of CIL to determine the elements of crimes against humanity to be misleading and foreign especially in view of the fact that it had earlier held that the Bangladesh legislation was consonant with CIL. However, having thus described the submissions of the defence, the Supreme Court went on to hold that "the prosecution [was] not require[d] to prove that while committing any of the offences there must be 'widespread and systematic' attack against "civilian population." ${ }^{\prime \prime 3}$ This is contrary to CIL under which (i) a widespread or systemic attack (ii) against a civilian population constitutes the chapeau or contextual elements of crimes against humanity. These chapeau elements serve to "elevate what would otherwise constitute a crime under domestic jurisdiction to an act of international concern. ${ }^{, 54}$ The Supreme Court in refusing to apply CIL had therefore removed the chapeau or contextual elements that are fundamental to the definition of crimes against humanity under CIL. As a result, Mr. Molla was convicted not for committing crimes against humanity as defined by CIL but for committing a domestic version of crimes against humanity unique to Bangladesh.

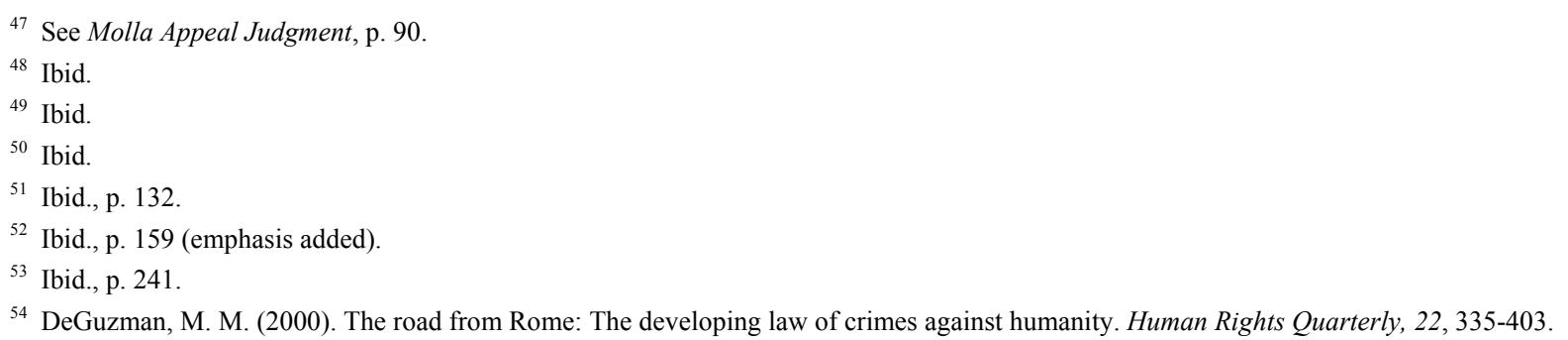


Further evidence of the Supreme Court's withdrawal from CIL is apparent from its comment made in relation to the trial judgment. The Supreme Court held that the observation in the trial judgment that the state had an obligation to bring to justice those who had committed crimes "in violation of customary international law" 55 was "based on a misconception." ${ }^{, 56}$ According to the Supreme Court, there was no obligation to try persons for committing offences (including crimes against humanity), the definitions and elements of which had been determined by CIL. ${ }^{57}$ This was a clear withdrawal from the rules of CIL that identify and describe international crimes.

\subsection{The Departure from the Default View}

The Supreme Court in relying on the Default View to withdraw from CIL had however ignored an important restriction imposed by Bradley and Gualti. Under the Default View, the right of unilateral withdrawal from CIL cannot be exercised to withdraw from jus cogens norms. Bradley and Gulati recognize that jus cogens norms stand on a higher footing than the rest of CIL and state that they "cannot be overridden, even by treaty, and there is no right to opt out of them by prior persistent objection." norms can be changed is through the development of a new conflicting jus cogens norm- something that is unlikely to occur. ${ }^{\circ 9}$ For Bradley and Gulati, jus cogens norms are an important exception to the right of unilateral withdrawal under the Default View.

Crimes against humanity are jus cogens offences. ${ }^{60}$ This was also recognized by the Supreme Court. ${ }^{61}$ Therefore, according to the Default View no withdrawal would be permitted from the rules of CIL that define and criminalize these crimes. However, the Supreme Court refused to apply CIL to identify the elements of crimes against humanity that characterize it as a jus cogens offence. As a result, the chapeau elements of crimes against humanity which are essential to its definition under CIL have no application in Bangladesh. ${ }^{62}$ Hence, the jus cogens offence of crimes against humanity is no longer recognized by Bangladesh. Bangladesh has therefore withdrawn from a jus cogens norm.

Bangladesh's withdrawal from CIL was effected on the basis of the Default View but without complying with the restrictions imposed by its proponents. While discussing the Default View, the Supreme Court made no reference to the restrictions on this model. In fact, although the Supreme Court found the Default View which allows a withdrawal from CIL helpful, the restriction on withdrawal from jus cogens norms was an impediment and the Supreme Court chose to ignore it. Bangladesh has therefore adopted a modified version of the Default View in which Bradley and Gulati's restrictions have no place and has thus justified Anthea Roberts's fear that states which endorse the Default View might "assert that it is applicable across the board, even with respect to core substantive norms and important structural constraints.",63

\subsection{The Implications of the Default View for Mr. Molla}

Abdul Quader Molla, an opposition political leader was tried and convicted by the International Crimes Tribunal of Bangladesh for committing crimes against humanity during the liberation war against Pakistan in 1971. The Tribunal which had applied the Mandatory View sentenced him to life imprisonment. However, the Supreme Court which acts as the appeals chamber of the Tribunal, on applying the Default View sentenced him to death. The selection of the model of CIL at the trial and appellate forums played an important role in the sentence that was handed down to Mr. Molla.

Mr. Molla was sentenced to death by the Supreme Court on 1 of 6 counts in the indictment. He was charged on

\footnotetext{
${ }^{55}$ Molla Appeal Judgment, p. 159-60.

${ }^{56}$ Ibid., p. 160.

${ }^{57}$ Although the Supreme Court refused to apply CIL and described the findings of the trial judgment insofar as they relied on CIL to be a misconception, the Supreme Court, rather confusingly also held that "CIL will be applicable so far as it is not inconsistent with the [Bangladesh legislation]." See ibid. at p. 159. However, this amounts to a mere lip service to the applicability of CIL as the Supreme Court nevertheless refused to apply CIL although it admitted quite clearly that it is consistent with domestic law. See ibid. at p. 132.

${ }^{58}$ Bradley \& Gulati (2010), p. 213 (footnotes omitted).

${ }^{59}$ Ibid.

${ }^{60}$ See Bassiouni, M. C. (1996). International crimes: Jus cogens and obligatio erga omnes. Law and Contemporary Problems, 59, 63-74; Bassiouni, M.C. (1999). Crimes against humanity in international law. The Hague, The Netherlands: Kluwer Law International.

${ }^{61}$ See Molla Appeal Judgment, pp. 112-113.

${ }^{62}$ See supra notes 52-54 and accompanying text.

${ }^{63}$ Roberts (2010), p. 185.
} 
this count for committing murder and rape as crimes against humanity during the liberation war. ${ }^{64}$ The Tribunal, which considered itself bound by CIL recognized the elements of crimes against humanity as defined by CIL. ${ }^{65}$ Under CIL, one of these elements required the Tribunal to show a nexus between the alleged acts of Mr. Molla and the attack carried out by the Pakistan Army during the war. ${ }^{66}$ However, due to the absence of any evidence as to nexus, the Tribunal dealt with the issue by holding that Mr. Molla had "culpable association"67 with the supporters of the Pakistan Army. The Tribunal found Mr. Molla's nexus with the attack by the Pakistan Army in his culpable association "with the gang of local Bihari hooligans who were quite antagonistic to the local Bengali people particularly who were in favour of self-determination movement of [the] Bengali nation." ${ }^{68}$ Biharis who form an ethnic group distinct from Bengalis ${ }^{69}$, had migrated into the territory of Bangladesh from the State of Bihar during the partition of India in 1947. Occasionally referred to as non-Bengalis, they had sided with the Pakistan Army during the liberation war. The Tribunal could not comprehend why a Bengali would want to associate with non-Bengalis during the months leading up to the war and posed the rhetorical questions, "Why the accused, being a [Bengali] civilian accompanied the local Bihari hooligans?" and "Why he used to maintain culpable association with them even since prior to 25 [M] arch 1971?" "70 For the Tribunal, Mr. Molla being a Bengali, his association with Biharis especially in the months preceding and during the liberation war constituted culpable conduct. This "culpable association" with pro-Pakistani and non-Bengali elements during the liberation war in the view of the Tribunal provided the necessary nexus between Mr. Molla and the attack of the Pakistan Army. The Tribunal had thus relied on a form of guilt by association to establish the nexus. However, the nexus being tenuous and weak, the Tribunal did not impose the maximum penalty of death.

The Government of Bangladesh appealed to the Supreme Court against the sentence and sought an enhancement. Although at the Tribunal the Prosecution had accepted the applicability of CIL to the Bangladesh trials, before the Supreme Court, the Attorney General argued against its applicability. ${ }^{71}$ The evidence presented before the Tribunal was not sufficient for proving all of the elements of crimes against humanity under CIL, including the requirement of a nexus with the attack. This had led the Government to re-evaluate its position on CIL. The Supreme Court accepted the arguments of the Government by adopting the Default View of CIL. It withdrew from the rules of CIL that determine the elements of crimes against humanity, which in turn permitted it to undermine the nexus requirement by describing it as misleading and foreign to the Bangladesh legislation. ${ }^{72}$ As a result, the Supreme Court, freed from the restraints of CIL was no longer burdened with the task to proving a nexus between the alleged acts of Mr. Molla and the attack. For the Supreme Court, the nexus requirement was not an element of crimes against humanity under Bangladesh law. Hence, any weakness in the evidence as to nexus was immaterial. Mr. Molla was sentenced to death and executed for committing crimes against humanity which had no proven nexus with the liberation war of 1971.

Had the Supreme Court adopted the Mandatory View of CIL, it would have been compelled to establish a nexus between the acts of Mr. Molla and the attack by the Pakistan Army. The Supreme Court would have encountered the same difficulties as the Tribunal with a lack of evidence in relation to this element. This weakness in the evidence of one of the elements of crimes against humanity would have made the imposition of capital punishment difficult to justify. The adoption of the Default View was therefore a crucial step which led to the enhancement of the sentence. Hence, Mr. Molla's execution was facilitated by a theoretical model of CIL which has not only been subject to widespread scholarly criticism, but one which also has no instance of application by any other state.

\section{Conclusion}

This is not the first time that Bangladesh has paid the price for reliance on theoretical models of iconoclast

\footnotetext{
${ }^{64}$ See Chief Prosecutor v. Abdul Quader Molla, ICT-BD Case No. 2 of 2012 (International Crimes Tribunal-2), Trial Judgment, February 5, 2013, (Molla Trial Judgment), para 335. Retrieved from http://ict-bd.org/ict2/ICT2\%20judgment/quader_full_verdict.pdf

${ }^{65}$ Ibid., para 72 ("Admittedly, the accused has been indicted for the crimes committed in violation of customary international law and thus this Tribunal shall not be precluded from borrowing guidance from the jurisprudence evolved to characterize the offences alleged as crimes against humanity.")

${ }^{66}$ See Prosecutor v. Kunarac, ICTY-IT-96-23 \& IT-96-23/1-A, Appeals Chamber, June 12, 2002, paras 91 \& 99.

${ }^{67}$ Molla Trial Judgment, para 145.

${ }^{68}$ Ibid., para 151 .

${ }^{69}$ Bengalis form the majority of the ethnic composition of Bangladesh.

${ }^{70}$ Molla Trial Judgment, para 355.

${ }^{71}$ See Molla Appeal Judgment, p. 537 (“The learned Attorney General remained intransigent on the view that Customary International Law provisions were incongruous to the trials under the Act.").

${ }^{72}$ See text accompanying infra notes 52 and 53.
} 
scholars. ${ }^{73}$ In 1958, the predecessor of the Supreme Court of Bangladesh, the Supreme Court of Pakistan, ${ }^{74}$ accorded legal recognition to a military takeover and the subsequent abrogation of the country's constitution by relying on Hans Kelsen's ${ }^{75}$ Pure Theory of Law. ${ }^{76}$ The Supreme Court of Pakistan held at the time that a coup d'etat was a recognized method of changing the constitution and that the military takeover had changed the grund norm or basic norm of the country. ${ }^{77}$ Though this decision was eventually overruled 14 years later in $1972,{ }^{78}$ its effect was that both Pakistan and Bangladesh have since been plagued by military takeovers.

There is yet another unfortunate similarity between the judgments of 1958 and 2013. The former Chief Justice of Pakistan was criticized for "thinking that [the Pure Theory of Law] was a generally accepted doctrine of modern jurisprudence." "79 The Supreme Court of Bangladesh too seems to have fallen into the same error in relation to the Default View. A model which was developed "primarily for scholars and students" $\mathrm{CIL}$ and which in the words of its own authors "has generated strong reactions" ${ }^{\text {} 81}$ now defines Bangladesh's position on CIL.

In 1958, the judgment had merely legitimatized a change of regime. On this occasion however, the judgment can have far-reaching consequences. CIL law no longer only regulates the relations between states but also confers rights upon its citizens. ${ }^{82}$ It has now become an important tool to be used in the last resort by citizens to assert their basic human rights against an oppressive state. If states are allowed to withdraw from CIL, this last resort will be undermined. It does not bode well for Bangladesh that despite a developing body of opinion that the rule of law now requires compliance with $\mathrm{CIL}^{83}$, the Supreme Court has decided to move in the opposite direction and rely on the Default View to withdraw from its rules. The Default View has allowed the Supreme Court to strip crimes against humanity of its elements under CIL thereby altering the character of these offences. For now, the Default View has resulted in the execution of one political leader. However, the path has been paved for further withdrawals. Anthea Roberts's warning that the Default View "might increase the prospect of opportunistic or abusive claims by unscrupulous states" ${ }^{\prime 84}$ can no longer be taken lightly. Further withdrawals from more fundamental rules of CIL may in the future prove to be catastrophic for the nation and its citizens. ${ }^{85}$

\section{Copyrights}

Copyright for this article is retained by the author(s), with first publication rights granted to the journal.

This is an open-access article distributed under the terms and conditions of the Creative Commons Attribution license (http://creativecommons.org/licenses/by/3.0/).

\footnotetext{
${ }^{73}$ I describe Bradley and Gulati as iconoclasts because they admit to challenging conventional wisdom. See text accompanying supra notes 21-23.

${ }^{74}$ The territory now known as Bangladesh was formerly a part of Pakistan. On March 26, 1971 Bangladesh declared independence from Pakistan.

${ }^{75}$ Lauterpacht describes Kelsen as an iconoclast and states that "there is hardly a leading doctrine or a conception of modern jurisprudence that he has not assailed." See Lauterpacht, H. (1975). International law, collected papers, (Vol- 2). Cambridge, England: Cambridge University Press.

${ }^{76}$ For a discussion on the Pure Theory of Law, see Kelsen, H. (1945). General theory of law and state (Anders Wedberg, Trans.). Cambridge, MA: Harvard University Press.

${ }^{77}$ See State v. Dosso, 1958 P.L.D. (S.C.) p. 533 (Pak. Sup. Ct).

${ }^{78}$ See Asma Jilani v. The Government of the Punjab, 1972 P.L.D. (S.C.) p. 139 (Pak. Sup. Ct.).

${ }^{79}$ Ibid., p. 181.

${ }^{80}$ Bradley \& Gulati (2010), p. 275.

${ }^{81}$ Bradley \& Gulati (2011), p. 423.

${ }^{82}$ See Crawford (2012), p. 17 ("It is no longer possible to deny that individuals may have rights and duties in international law.").

${ }^{83}$ See Bingham, T. (2011). The rule of law. London, England: Penguin Books.

${ }^{84}$ Roberts (2010), p. 185.

${ }^{85}$ See Wahid, M. R. \& Hannah, J. (2014, January 3). Return of the basket case. Foreign Policy. Here the authors express the fear that "[t]he precedent set by the lack of internationally acceptable judicial process in these trials means there is no telling what will come next ...." Retrieved from http://www.foreignpolicy.com/articles/2014/01/03/return_of_the_basket_case_bangladesh
} 